\title{
Lineamentos de uma Constituição realista para o Brasil (*)
}

\section{Goffredo Telles Junior}

Catedrático de Introdução a Ciência do Direito na Universidade de São Paulo.

O Govêrno do Brasıl, pondo sua confiança em Deus, obediente aos imperativos da honra e do patriotismo, preso ao dever de conseguir a justiça social dentro da ordem juridica, perseverante no propósito de manter o império da Lei, como condição primária da Liberdade;

e considerando:

1. que as Nações têm uma constituição natural, que não é prudente substituir por estruturações artificiais;

2. que as fórmulas políticas do século $\mathrm{xIx}$ não se adaptam às condições sociais do Século xx;

3. que o Brasil é uma realidade que não pode ser contrafeita por mitos constitucionais;

4. que uma Constituição não deve conter matéria de legislação ordinária;

5. que o povo clama por um regime de autenticidade, inspirado nas augustas tradições da Pátria;

Resolve adotar, cumprir e fazer cumprir a presente constituição.

(*) Este trałalho exprime, em forma de lei, os princípios expostos pelo autor na Aula Solene de abertura dos Cursos Jurídicos em 1956, na Faculdade de Direito da Universidade de São Paulo. 


\section{CAPÍTULO I \\ Declaração de direitos}

Art. 1. Os direitos fundamentais do homem, como os que concernem à vida, à liberdade, à segurança pessoal, à família, à corporação, à propriedade privada, ao trabalho, são condições inerentes à natureza humana, atributos impostergáveis, que não podem, sem violência, ser negados por qualquer legislação positiva. Todo atentado contra tais direitos tem que ser considerado crime. Todo cerceamento injusto da liberdade individual é prepotência. E tôda tirania é intolerável.

Art. 2. Todos são iguais perante a lei.

Art. 3. Ninguém é obrigado a fazer ou a deixar de fazer alguma coisa, senão em virtude da lei.

Art. 4. Salvo as exceções legais, a lei não retroage e só estatui para o futuro. A lei velha sobrevive à lei nova, em relação aos efeitos presentes já objetivados na situação jurídica definitivamente estabelecida sob a vigência da lei velha.

Art. 5. É. livre a manifestação do pensamento. Não podem, contudo, ser admitidos os espetáculos que causem escândalo público, assim como é vedada a propaganda da guerra e o estímulo aos processos violentos para a subversão da ordem. É livre o exercício dos cultos religiosos, exceto os que perturbem a ordem pública ou contrariem os bons costumes. Quem, entretanto, invocando crença ou convicção, recusar obrigação, encargo ou serviço, imposto por lei, poderá ser privado de seus direitos políticos e mesmo de sua nacionalidade brasileira. As Fôrças Armadas têm direito à assistência religiosa. As confissões religiosas podem praticar seus ritos nos cemitérios, assim $10-2^{\circ}-$ F. D. 
como também, na forma da lei, manter cemitérios particulares (art. 64). É inviolável o direito de reunião, podendo a polícia designar o local em que a reunião se deva realizar, contanto que, assim procedendo, não a frustre ou impossibilite. É garantida a liberdade de associação para fins lícitos. Os partidos políticos podem organizar-se e funcionar na fornı da lei. Não é permitido, porém, o registro, organização e funcionamento de associações políticas, cujo programa ou ação revele sua articulação com associações políticas ou governos estrangeiros, ou sua intenção de subverter, pela violência, a ordem instituída. Nenhuma associação pode ser dissolvida senão em virtude de sentença judiciária. É assegurado o direito de resposta. $\mathrm{O}$ anonimato não é permitido. $\mathrm{O}$ sigilo da correspondência é inviolável.

Autonomia das corporaçōes.

Familia.
Art. 6. As Corporações domésticas, econômicas, culturais e religiosas (art. 28) são autônomas perante o Estado.

Art. 7. O casamento civil é celebrado gratuitamente pelo Estado. O casamento religioso equivale ao civil, se assim o requerer o celebrante ou qualquer interessado, respeitados os impedimentos e as prescrições da lei, e a partir do momento e que o ato seja inscrito no registro público.

Educação.

Art. 8. O ensino primário é obrigatório. $\mathrm{O}$ ensino primário oficial é gratuito para todos. Os Poderes Públicos municipais, provinciais e nacional terão magistério oficial e estabelecimentos de ensino. E livre a iniciativa particular em matéria de ensino, respeitadas as leis que o regulam. O professor primário, em estabelecimentos oficiais de ensino, perceberá vencimentos iguais aos de professor secundário. $O$ provimento de cátedras no ensino secundário oficial e o ingresso na carreira de professor universitário se faz por concurso de títulos e provas. A 
lei regulará a carreira de professor universitário. São vitalícios os professôres admitidos por concurso de títulos e provas. É garantida a liberdade de cátedra. Os Poderes Públicos manterão institutos, aparelhagem e cursos para o aprimoramento da cultura e para o progresso das ciências, letras e artes. Promoverão intercâmbio cultural com as outras nações. O livro, nacional ou estrangeiro, não será objeto de tributação específica.

Art. y. O domicílio é inviolável. Exceções a esta regra só podem ser admitidas, na forma que a lei estabelecer, em caso de crime, de desastre ou de extrema e comprovada necessidade pública.

Art. 10. A propriedade privada é inviolável, salvo hipótese de desapropriação pelo poder público. O proprietário tem o direito de usar, gozar e dispor livremente de seus bens, dentro dos limites impostos pelo bem comum, assim como de rehavê-los de quem injustamente os possua. Entende-se por bem comum a ordem juridica instituída. A desapropriação, que será regulada por lei, só se dará por necessidade ou utilidade pública, e mediante prévia e justa indenização em dinheiro. Em caso de perigo iminente, como guerra ou comoção intestina, as autoridades competentes poderão fazer uso da propriedade particular, se assim o exigir o bem público, ficando assegurado, ao proprietário, o direito à indenização ulterior. O Govêrno Nacional, mediante lei especial, pode intervir em emprêsa econômica particular. A intervenção, entrełanto, só se faz a título de exceção, para a defesa necessária de manifesto interêsse público, e tem por limites os direitos fundamentais, assegurados nesta Constituição. A exploração ou o aproveitamento industrial de minas, jazidas e quedas dágua depende de autorização ou concessão do Govêrno Nacional. As autorizações ou concessões só podem ser conferidas a brasileiros ou a sociedades organizadas e dirigidas por brasileiros, assegurado ao proprietário do solo preferência para a exploração ou o aproveita-

Direito de propriedade. 
mento dessas riquezas. Quando o proprietário do solo não se quizer valer de tal preferência, terá êle direito, nos termos da lei, de participar da administração e dos lucros da emprêsa, que se instale em sua propriedade para aquêle fim. Não depende de autorização ou concessão, o aproveitamento de energia hidráulica de potência reduzida. Satisfeitas as exigências da lei, entre as quais a de serviços técnicos e administrativos provadamente idôneos, os Governos Provinciais, por delegação do Govêrno Nacional, ficarão incumbidos de conferir as mencionadas autorizações e concessões. Os brasileiros natos, que, sem objeção do Poder Público, sejam posseiros de terras devolutas, com morada habitual nas mesmas, por mais de cinco anos consecutivos, terão preferência para aquisição dessas terras, até o limite de área que a lei fixará. Sem parecer favorável do Senado, não é permitida alienação ou concessão de terras públicas com área superior a dez mil hectares. Todo brasileiro nato que, não sendo proprietário rural ou urbano, ocupar, por dez anos ininterruptos, trecho de terra não superior a vinte e cinco hectares, tornando-o produtivo por seu trabalho e tendo nêle sua morada habitual, sem que tenha havido reconhecimento de domínio alheio, com ciência e sem oposição por parte do legítimo dono, poderá obter domínio sôbre essa terra, mediante sentença declaratória devidamente transcrita. Os inventos industriais pertencem a seus autores, aos quais a lei garantirá o privilégio temporário de direito exclusivo sôbre os mesmos, direito êste que poderá ser substituído por compensação adequada em dinheiro, se a vulgarização do invento convier à coletividade. É assegurada a propriedade das marcas de indústria e comércio, bem como a exclusividade de uso do nome comercial. É assegurado o direito de autor, nos termos e condições que forem estipulados por lei. Sociedades anônimas por ações ao portador e pessoas físicas ou jurídicas de nacionalidade estrangeira não podem ser proprietárias ou acionistas de emprêsas de jornais, de rádio-difusão e de televisão, assim como de quais- 
quer outras emprêsas úteis à defesa nacional que, como tais, venham a ser classificadas por lei. Os navios nacionais só podem pertencer a brasileiros.

Art. 11. É livre o exercício de qualquer profissão, observadas as condições que a lei estabelecer. A lei disporá sôbre os direitos e deveres dos empregados e empregadores.

Art. 12. É assegurado o direito de representação ao Poder Público. Relativamente aos processos nas repartições públicas, a lei assegurará: 1. rápido andamento; 2. ciência das informações e dos despachos neles exarados, a todos os que sejam nos mesmos diretamente interessados; 3 . expedição das certidões requeridas, salvo se o interêsse público impuzer sigilo.

Art. 13. Qualquer cidadão é parte legítima para pleitear a anulação ou a declaração de nulidade de atos que lesem o patrimônio da União, das Províncias, dos Territórios, dos Municípios, das entidades autárquicas e das sociedades anônimas de economia mixta.

Art. 14. Nenhuma ação será considerada crime, sem lei anterior que como tal a qualifique. Nenhuma pena será imposta, sem lei anterior que a comine. Não há pena de morte, de banimento e de confisco. Não há pena perpétua. Não há prisão por dívida, nem por multa ou custas, salvo caso do depositário infiel e de inadimplemento de obrigação alimentar. São ressalvadas, quanto à pena de morte, as disposições da legislação militar em tempo de ฐuerra com país estrangeiro. A lei disporá sôbre o seqüestro e o perdimento de bens, no caso de enriquecimento ilícito, por abuso de função em pôsto público ou em emprêgo de entidade autárquica. Medidas serão adotadas por lei para o objetivo da individualização da pena. A lei penal retroage quando beneficia o réu. Nenhuma pena passará da pessoa do delinqüente.

Ação popular.

Direito de representação. 
Prisão

ilegal.

Habeas corpus o mandado de segurança.

Ação judiciârla.

Extradição e expulsåo.
Art. 15. Ninguém será preso senão em flagrante delito ou, nos casos expressos em lei, por ordem escrita da autoridade competente. Ninguém será mantido em prisão antes do julgamento, desde que preste fiança idônea, nos termos e limites que a lei fixará. A prisão ou detenção ilegal acarreta a responsabilidade da autoridade coatora.

Art. 16. Sempre que solicitado, sera concedido habeas corpus a favor de quem sofrer, ou se achar ameaçado de sofrer, por parts do Poder Público, atentado ilegal contra sua liberdade de locomoção. Dar-se-á mandado de segurança quando a violência, por parte do Poder Público, atingir direito líquido e certo, não amparado por habeas corpus.

Art. 17 A lei não poderá excluir da apreciação do Organismo Judiciário qualquer lesão de direito individual. Ninguém será processado nem sentenciado senão pela autoridade competente e na forma de lei anterior. Não há fôro privilegiado, nem juízes e tribunais de exceção. É da competência do Tribunal do Juri, o julgamento dos crimes dolosos contra a vida e contra a honra. É assegurado aos acusados pleno direito de defesa, com todos os meios e recursos essenciais a ela, desde a expedição do mandado de prisão. O mandado de prisão tem que ser assinado pela autoridade competente e deve mencionar, com clareza, o fato que motiva a prisão. Uma cópia autêntica do mandado será obrigatória e imediatamente entregue ao prêso. A instrução criminal é contraditória. Os necessitados têm direito à assistência judiciária, fornecida gratuitamente pelo Poder Público.

Art. 18. Não será concedida extradição de estrangeiro por crime político ou de opinião. Só podem ser extraditados réus de crime comum, a pedido oficial do país em que o mesmo tenha sido praticado e após julgamento e condenação definitiva em processo regular. Em caso nenhum, será concedida extradição de brasileiro. 0 
Govêrno pode expulsar do território nacional o estrangeiro nocivo à ordem pública, salvo se seu cônjuge for brasileiro e se tiver filho brasileiro, dependente da economia paterna.

Art. 19. A entrada e permanência de estrangeiros no território nacional será regulada por lei.

Art. 20. O Presidente da República pode decretar o estado de sítio: 1 . no caso de comoção intestina grave, irrompida ou iminente; 2 . no caso de guerra externa. O necreto do estado de sítio especificará: 1. as normas a que deve obedecer sua execução; 2. os direitos e garantias que são suspensos; 3. os casos em que os autores de crimes contra a segurança da Nação ou das instituições políticas devem ficar sujeitos à jurisdição e à legislação militar; 4. as regiões sujeitas ao estado de sítio; 5 . o tempo de sua duração. Publicado o decreto, o Presidente da República enviará mensagem especial ao Conselho Nacional, relatando os motivos da decretação. O Conselho Nacional, em sessão secreta, passará incontinenti a deliberar sôbre o decreto, para mantê-lo ou revogá-lo. Só poderá revogá-lo, porém, pelo voto de dois terços de seus membros. Se o Conselho Nacional estiver em férias, será imediatamente convocado para essa deliberação. Durante o estado de sítio por comoção intestina, só se poderão tomar as seguintes medidas contra pessoas sem culpa formada em processo, mas tidas como suspeitas ou prejudiciais à segurança pública: 1 ordem de permanência em localidade determinada; 2 . detenção em edifício onde não se encontrem réus de crimes comuns; 3 . destêrro para localidade povoada e salubre. O Presidente da República, outrossim, poderá determinar: 1. censura de correspondência e de publicidade, inclusive da publicidade feita pelo rádio, televisão, cinema e teatro; 2 . suspensão da liberdade de reunião, inclusive a que seja exercida no seio das associações; 3 . busca e apreensão em domicílio; 4 . suspensão de funcionário público, de empregado de pessoa
Entrada o permanêncla de estrangeiros no Território nacional.

Estado de sítio. 
jurídica de direito público, de entidade autárquica, de sociedade de economia mixta ou de emprêsa concessionária de serviço público; 5 . intervenção em emprêsa de serviços públicos. As imunidades dos Senadores e Conselheiros subsistem durante o estado de sítio, podendo entretanto ser suspensas, mediante o voto de dois terços dos membros de suas respectivas Casas, para aquêles Senadores e Conselheiros cuja liberdade se tornou manifestamente incompatível com a defesa da Nação ou com a segurança das instituições políticas. O estado de sítio no caso de comoção intestina não pode ser decretado por prazo superior a trinta dias, nem prorrogado, de cada vez, por prazo superior a êsse. A prorrogação depende de autorização do Conselho Nacional. O estado de sítio por motivo de guerra externa pode ser decretado por todo o tempo da guerra. Expirado o estado de sítio, com êle cessarão seus efeitos. As medidas aplicadas durante sua vigência, com as respectivas justificações, serão relatadas pelo Presidente da República ao Conselho Nacional. A inobservância de qualquer das prescrições dêste artigo torna ilegal a coação e dará direito, aos pacientes, de recorrerem à Justiça.

\section{CAPÍTULO II \\ Da nacionalidade e dos direitos políticos}

Nacionalldade brasileira.
Art. 21. São brasileiros: 1. os nascidos no Brasil, ainda que de pais estrangeiros, não estando êstes a serviço oficial de seu país; 2 os filhos de brasileiro ou brasileira, nascidos no estrangeiro, se os pais estiverem a serviço oficial do Brasil, ou não o estando se vierem residir no Brasil; 3. os que adquiriram a nacionalidade brasileira nos termos do artigo 69, ns. 4 e 5, da Constituição de 24 de Fevereiro de $1891 ; 4$. os naturalizados pela forma que a lei estabelecer, sendo que, para a naturalização de cidadãos de raça portuguêsa, nascidos em Portugal, só se exigem domicílio no Brasil e idoneidade moral. 
Art. 22. Perde a nacionalidade o brasileiro: 1. que, por naturalização voluntária, adquirir outra nacionalidade; 2. que, sem licença do Presidente da República, aceitar, de govêrno estrangeiro, comissão, emprêgo ou pensão; 3 . que, por sentença judicial, em ação cujo processo a lei estabelecerá, tiver cancelada sua naturalização, por exercer atividade nociva ao interêsse nacional, ou recusar obrigação, encargo ou serviço, imposto por lei (Art. 5). A lei estabelecerá as condições de reaquisição da nacionalidade brasileira.

Art. 23. Todo brasileiro, sem distinção de sexo, instrução ou categoria social, adquire direitos políticos ao filiar-se a uma Corporação (Art. 28). Não pode filiar-se a uma Corporação quem estiver cumprindo pena, ou tiver sido reincidente em crime comum ou de responsabilidade.

Art. 24. São eleitores os brasileiros que se alistarem na forma da lei. O alistamento é obrigatório para os brasileiros que estiverem em condições legais de fazê-lo. Não pode ser eleitor: 1. quem não fôr maior de vinte e um anos; 2. quem não tiver concluído o curso de ensino primário; 3 . quem não se tiver filiado a uma Corporação. Também não podem alistar-se eleitores os Senadores Nacionais e Provinciais (Art. 46 e 34), as praças de pré, salvo os aspirantes a oficial, os sub-oficiais, os subtenentes os sargentos e os alunos das escolas militares de ensino superior. Não se exigirá conclusão do curso primário a quem, sabendo ler e escrever correntemente, tenha mais de 21 anos de idade, na data desta Constituição.

Art. 25. Suspendem-se os direitos políticos: 1 por incapacidade civil absoluta; 2 . por condenação criminal, enquanto durarem seus efeitos. Perdem-se os direitos políticos: 1. por perda da nacionalidade de brasileiro; 2. pela recusa de obrigação, encargo ou serviço, prevista no art. 5; 3. pela aceitação de título nobiliário ou condecoração estrangeira, que importe restricão de direito ou dever

Aquisição de direitos políticos.

Eleltores.

Suspensāo e perda de direitos políticos. 
perante o Estado. A perda dos direitos políticos acarreta, simultâneamente, a perda do cargo ou função pública. A lei estabelecerá as condições de reaquisição dos direitos políticos.

Inelegibilidade.
Art. 26. São inelegíveis os inalistáveis (art. 24) São também inelegiveis:

I. Para Presidente e Vice-Presidente da República:

a) o Presidente, que tenha tido o cargo por qualquer tempo, no período imediatamente anterior à eleição; ou o Vice-Presidente que lhe tenha sucedido; ou, ainda, quem, dentro dos seis meses anteriores ao pleito, por qualquer razão de Estado, o tenha substituído; b) os Governadores, os Interventores (Art. 36 e 57), os Ministros de Estado e o Prefeito da Capital da República, se não se afastarem, definitivamente, de suas funções, ao menos seis meses antes da eleição; c) os Ministros do Supremo Tribunal, o Procurador Geral da República, os Chefes do Estado Maior, os Juízes, o Procurador Geral e os Procuradores Regionais da Justiça Eleitoral, os Secretários de Estado e os Chefes de Polícia, se suas funções não cessarem, definitivamente, ao menos três meses antes da eleição; d) os cônjuges e parentes consanguíneos ou afins, até o segundo grau, do Presidente e do Vice-Presidente, cujo mandato tenha ocorrido no período imediatamente anterior à eleição.

II. Para Governador:

a) em cada Província, o respectivo Governador, que tenha tido o cargo por qualquer tempo, no período imediatamente anterior à eleição; ou quem lhe haja sucedido; ou, ainda, quem, dentro dos seis meses anteriores ao pleito, por qualquer razão de Estado, o tenha substituido; e o Interventor (Art. 36 e 57), que tenha exercido as funções governamentais por qualquer tempo, no período imediatamente anterior à eleição; b) o Presidente e o Vice-Presidente da República, assim como 
os substitutos que hajam assumido a Presidência, se não se afastarem, definitivamente, de suas funções, ao menos um ano antes da eleição; c) em cada Província, os respectivos Secretários de Estado, Comandantes das Regiões Miliiares, Chefes e Comandantes de Polícia, Magistrados da República e das Províncias, o Chefe do Ministério Público e o Prefeito da Capital, se suas funções não cessarem, definitivamente, ao menos seis meses antes da eleição; d) os que forem inelegiveis para Presidente da República, se suas funções não cessarem, definitivamente, três meses antes da eleição, sem prejuizo do que se acha estipulado nas letras "a" e "b" dêste número; e) os cônjuges e parentes consanguíneos ou afins, até o segundo grau, do Presidente, Vice-Presidente e Governador, cujo mandato haja ocorrido no período imediatamente anterior à eleição.

III. Para Prefeito:

a) em cada Município, o respectivo Prefeito, que tenha tido o cargo por qualquer tempo, no periodo imediatamente anterior à eleição; ou quem lhe haja sucedido; ou, ainda, quem, dentro dos seis meses anteriores ao pleito, o tenha substituído; b) as autoridades policiais sediadas no Município, si não se afastarem, definitivamente, de suas funções, ao menos seis meses antes da eleição; c) o cônjuge e os parentes consanguíneos ou afins, até o segundo grau, do Prefeito cujo mandato haja ocorrido no período imediatamente anterior ao pleito.

\section{CAPÍTULO III}

\section{Da organização política}

Art. 27. O Brasil é um Império. A forma de seu govêrno é republicana. A grandeza nacional resulta da união perpétua e indissolúvel de suas Províncias e de seus Territórios. As Províncias e os Territórios se compõem de Municípios. Nos Municípios, geram-se e desenvolvem-se

Forma do govêrno. Partes de que se compõe a Nação Brasileira. 
os grupos naturais da sociedade. Dêles emanam a Lei e o Poder.

Organização corporativa.
Art. 28. A lei disporá sôbre a organização corporativa dos grupos domésticos, econômicos, culturais e religiosos, respeitadas as seguintes normas:

I. É livre o direito de associação e de sindicalização, para a defesa e o exercício de qualquer categoria de atividade lícita. Mas só serão consideradas Corporações, as associações que o Poder Público reconhecer como representantes legais, dentro dos respectivos Municípios, de determinada categoria de atividade.

II. As Corporações não são órgãos do Poder Público, mas é de seu dever cooperar, ao máximo, dentro de seu campo de ação, na defesa dos altos interêsses do País. A lei fixará, tão sòmente, o plano fundamental da organização corporativa, respeitado o princípio da autonomia das Corporações (Art. 6).

III. A associação em que se defendam, concomitantemente, interêsses de empregados e de empregadores de um determinado ramo econômico, só poderá ser constituída em Corporação se nela estiverem efetivamente representados um sindicato de empregados e um sindicato de empregadores do mesmo ramo econômico.

IV Em cada Município, só poderá existir uma Corporação para cada categoria de atividade.

V. No plano provincial, cada categoria de atividade poderá ter sua Federação Corporativa, constituída por mandatários das respectivas Corporações. No plano nacional, cada categoria de atividade poderá ter sua Confederação Corporativa, constituída de mandatários das respectivas Federações Corporativas.

VI. As instituições corporativas são fontes de direito, e exercerão função legislativa, nos termos dos artigos 52 e 53 desta Constituição. 
Art. 29. O Municipio é governado por um Prefeito e Govêrno e autonomia por um Conselho Municipal. A êstes dois órgãos compete dos administrar o Município no que concerne a seu peculiar Municípios. interêsse, e, especialmente: 1. à decretação dos tributos de sua competência e à aplicação de suas rendas; 2 . à organização e execução de obras e serviços públicos locais. Ao Conselho Municipal compete sugerir ao Governador e ao Presidente da República, medidas e projetos de lei, que sejam considerados de interêsse geral. Serão nomeados pelos Governadores os Prefeitos: 1. das Capitais das Províncias; 2. dos Municípios que a lei, após parecer do Conselho de Segurança Nacional, declarar bases ou portos militares de importância para a defesa externa do País. Os Governos Provinciais não intervirão nos Municípios, senão para lhes regularizar as finanças, quando: 1 . derem prova de impontualidade no serviço de dívidas municipais garantidas pelo Govêrno Provincial; 2. deixarem de solver, por dois anos consecutivos, as obrigações decorrentes de sua dívida fundada.

Art. 30. O Prefeito e os Conselheiros Municipais são eleitos pelo voto secreto dos eleitores de seus respectivos Municípios. A eleição se faz, simultâneamente, em todos os Municípios do território nacional. Cada Município terá um número de Conselheiros que leis provinciais fixarão periòdicamente, atendendo ao critério da representação proporcional, não podendo ser maior do que quinze. A proporção de Conselheiros será uniforme em todo o País (Art. 50 e 57). O mandato é de cinco anos. São condi(cões para a investidura nos cargos de Prefeito e de Conselheiro: 1 ser brasileiro nato; 2. ser eleitor; 3. ser maior de vinte e cinco anos.

Art. 31. Cada Província se regerá por Constituição e Jeis que adotar, respeitadas as normas estabelecidas nesta Constituição. A administração dos Territórios se regerá por lei nacional.

Prefeito e Conselheiros Municipais.

Constituição provincial e administração dos Territórios. 
Govêrno

Provincial.

Governador.

Senado Provinciai.

Conselho Provincial.
Art. 32. A Província é governada por um Grovernador e um Senado, coadjuvados por um Conselho Provincial.

Art. 33. O Governador é eleito pelo voto secreto de todos os Conselheiros Municipais, existentes na Provincia. A eleição se faz, simultâneamente, em tôdas as Províncias, doze meses após cada eleição dos Conselhos Municipais. São condições para a investidura no cargo de Governador: 1. ser brasileiro nato e filho de brasileiros natos; 2 . ser eleitor; 3 . ser maior de trinta anos.

Art. 34. O Senado Provincial, em tudo que lhe for aplicável, está sujeito às normas que disciplinam o Senado Nacional. O número de Senadores, em cada Senado Provincial, será fixado por lei provincial, não podendo ser menor do que cinco, nem maior do que quinze. Em caso de vaga, o novo Senador, chamado a preenchê-la, será eleito pelos Desembargadores do Tribunal de Justiça, dentre cinco nomes, indicados pelo próprio Senado. Os vencimentos de Senador são iguais aos de Desembargador.

Art. 35. O Conselho Provincial é composto de membros eleitos pelo voto secreto de todos os Conselheiros $\mathrm{Mu}$ nicipais, existentes na Província. A eleição se faz juntamente com a de Governador. Cada. Província terá um número de Conselheiros que lei nacional fixará periòdicamente, atendendo ao critério da representação proporcional, não podendo ser maior do que trinta. A proporção de Conselheiros será uniforme em todo o País (Arts. 50 e 57). São condições para a investidura no cargo de Conselheiro: 1. ser brasileiro nato; 2. ser eleitor; 3 . ser maior de trinta anos. Compete ao Conselho Provincial: 1. sugerir ao Governador e ao Presidente da República medidas e projetos de lei, que sejam considerados de interêsse geral; 2. exercer vigilância sôbre os atos do Poder Público, pronunciar-se sôbre a administração da Província e dos Municípios, e denunciar as irregularidades por ventura verificadas; 3 . representar ao Govêrno Nacional e manifestar-se perante quaisquer autoridades do País e perante a opinião pública, sôbre questões 
de importância capital para a defesa do bem comum; 4 . decidir, pelo voto da maioria absoluta de seus membros, sôbre o recebimento ou não recebimento de acusação contra o Governador ou contra os Secretários de Estado, para o fim de, no caso de ser admitido o recebimento, submeter-se o acusado a julgamento perante o Tribunal de Justiça, nos crimes comuns, ou perante o próprio Conselho Provincial, nos de responsabilidade; 5. julgar o Governador e os Secretários de Estado, nos crimes de responsabilidade. As Constituições Provinciais poderão ampliar essa competência, não sendo permitido, porém, conferir a Conselho Provincial funções legislativas. Os Conselheiros Provinciais têm as garantias de que gozam os Senadores. No fim de cada mandato, o Co:iselho fixará o subsídio a vigorar durante o período seguinte. Havendo omissão desta providência, entender-se-á que a base do subsídio não foi alterada.

Art. 36. As Províncias ocorrerão às necessidades de seu govêrno e de sua administração, cabendo ao Govêrno Nacional prestar-lhes auxílio, em caso de calamidade pública. Mediante acôrdo com o Govèrno Nacional, os Governos Provinciais poderão encarregar funcionários nacionais da execução de leis e serviços provinciais ou de atos e decisões de suas autoridades. O Govêrno Nacional não intervirá nas Províncias, salvo para: 1. manter a integridade nacional; 2. repelir invasão estrangeira ou invasão de uma Província por outra; 3. pôr têrmo à guerra civil; 4. fazer respeitar a Constituição; 5. garantir o livre funcionamento dos altos órgãos dos Governos Provinciais; 6 . assegurar a execução de ordem ou decisão judiciária; 7 . reorganizar as finanças da Província que, sem motivo de fôrça maior, suspender, por mais de dois anos consecutivos, o serviço de sua dívida externa fundada.

Art. 37 A Nação é governada pelo 'Presidente da República e pelo Senado Nacional, coadjuvados pelo Con-

Autonomia provincial. 
dimento, e sucede-lhe, no de vaga, o Vice-Presidente da República. Em caso de impedimento ou vaga do Presidente e do Vice-Presidente, serão sucessivamente chamados ao exercício da Presidência, o Presidente do Supremo Tribunal e o Presidente do Senado Nacional. Vagando os cargos de Presidente e Vice-Presidente da República na primeira metade do período presidencial, far-se-á eleição de novas autoridades para êsses postos, sessenta dias depois de aberta a última vaga. Os eleitos deverão completar o período de seus antecessores.

Eleição, inelegibilidade, posse e ausência do Presidente e VicePresidente.
Competência do Presidente.
Art. 38. O Presidente e o Vice-Presidente são eleitos pelo voto secreto de todos os Conselheiros Provinciais e Municipais, existentes no País. A eleição se faz três anos após a eleição dos Conselheiros Municipais. São condições para a investidura nos cargos de Presidente e VicePresidente: 1. ser brasileiro nato e filho de brasileiros ıatos; 2 . ser eleitor; 3 . ser maior de trinta e cinco anos. O Presidente e o Vice-Presidente tomam posse em sessão do Conselho Nacional ou, se êste não estiver reunido, perante o Supremo Tribunal. No ato de posse, o Presidente prestará o seguinte compromisso: "Prometo cumprir e fazer cumprir a Constituição e as leis do Brasil. Prometo fazer o que esteja a meu alcance para a felicidade da Nação" Se, decorridos trinta dias da data fixada para a posse, o Presidente ou o Vice-Presidente, salvo por motivo de doença, não tiver assumido o cargo, êste será declarado vago pelo Tribunal Superior Eleitoral. O Presidente e o Vice-Presidente não poderão ausentar-se do País, sem permissão do Conselho Nacional, sob pena de perda do cargo.

Art. 39. Cabe ao Presidente da República a suprema responsabilidade de superintender a administração gerai do País, cumprindo-lhe, com o auxílio dos demais órgãos do Govêrno e, dentro do campo de ação que lhe concedem as leis, prover tudo quanto seja útil ou se faça necessário ao bem estar, segurança e progresso da Nação. Para êsses 
objetivos, compete ao Presidente da República: 1. Propor, sancionar, promulgar e fazer publicar leis nacionais, assim como expedir decretos e regulamentos para sua fiel execução; 2. vetar, nos termos do artigo $54 ; 3$. nomear e demitir Ministros de Estado; 4. nomear e demitir os Governadores dos Territórios; 5. nomear e demitir o Prefeito da Capital da República; 6. prover, na forma da lei, os cargos públicos nacionais; 7. manter relações com Estados estrangeiros; 8. celebrar tratados e convenções internacionais, ad referendum do Senado Nacional; 9. declarar guerra, depois de autorizado pelo Conselho Nacional, ou sem essa autorização, no caso de súbita agressão estrangeira, verificada durante as férias do Conselho; 10 . fazer a paz, com autorização e ad referendum do Conselho Nacional; 11. permitir, depois de autorizado pelo Conselho Nacional, ou sem essa autorização durante as férias do Conselho, que fôrças estrangeiras transitem pelo território do País, ou, por motivo de guerra, nele permaneçam temporàriamente; 12. exercer o comando supremo das Fôrças Armadas, administrando-as por intermédio dos órgãos competentes; 13. decretar a mobilização total ou parcial das Fôrças Armadas; 14. decretar, prorrogar e suspender o estado de sítio, nos termos do artigo 20; 15 decretar e executar a intervenção do Govêrno Nacional nas Províncias, para os fins mencionados no artigo 36, ad referendum do Conselho Nacional; 16. autorizar brasileiros a aceitarem pensão, emprêsa ou comissão de govêrno estrangeiro; 17 enviar ao Senado Nacional, até 30 de Maio de cada exercício, a proposta de orçamento do exercício seguinte; 18. prestar, ao Conselho e ao Senado, dentro dos primeiros três meses de cada exercício, as contas relativas ao exercício anterior; 19. remeter mensagem às duas Câmaras, por ocasião da abertura dos trabalhos anuais, dando conta da situação do País e solicitando as providências que julgar necessárias; 20. conceder indulto e comutar penas, com audiência dos órgãos competentes. 
Competência privativa do VicePresidente.

Responsabilidade do Presidente.

Ministros de Estado.
Art. 40. Ao Vice-Presidente da República, compete exercer as funções de Presidente do Conselho Nacional, onde apenas tem voto de qualidade.

Art. 41. As acusações contra o Presidente da República importam sempre rigorosa responsabilidade civil e criminal de seus autores. Só o Conselho Nacional tem alçada para receber acusações contra o Presidente da República. Recebida a acusação, será o Presidente da República submetido a julgamento perante o Supremo Tribunal nos crimes comuns, ou perante o Conselho Nacional nos de responsabilidade (Art. 48). Uma vez decidido pelo Conselho Nacional o recebimento da acusação, ficará o Presidente suspenso de suas funções. São crimes de responsabilidade os atos do Presidente que atentarem contra as disposições desta Constituição e, especialmente, contra: 1. a existência e a segurança do Estado; 2. a preservação irrestrita e incondicional do território brasileiro; 3 . os direitos perpétuos e indivisiveis da soberania nacional; 4 . o livre funcionamento do Senado Nacional, do Conselho Nacional e dos órgãos da Justiça; 5. o livre exercício dos direitos políticos; 6 ; a segurança interna do País; 7. a probidade na administração; 8 . a lei orçamentária; 9. a guarda e o legal emprêgo dos dinheiros públicos; 10. o cumprimento das decisões judiciárias. Ésses crimes são definidos em lei especial, que estabelece as normas de processo e julgamento.

Art. 42. O Presidente da República é auxiliado pelos Ministros de Estado. São condições para a investidura no cargo de Ministro: 1. ser brasileiro nato; 2. ser eleitor; 3. ser maior de trinta anos. Além das atribuições que a lei fixar, compete aos Ministros: 1. referendar os atos assinados pelo Presidente da República; 2. expedir instruções para a bôa execução das leis, decretos e regulamentos; 3. praticar os atos administrativos necessários a êsse fim; 4. apresentar ao Presidente relatório anual dos serviços 
realizados no Ministério; 5. prestar as informações que lhes forem solicitadas pelo Senado Nacional, nos termos dos artigos 44 e 53. Nos casos de acusações contra Ministros e nos do respectivo julgamento, aplicam-se as normas do artigo 41 e 48 . O Ministro que não atender à convocação do Senado Nacional, comete crime de responsabilidade. Os Ministros são responsáveis pelos atos que assinarem juntamente com o Presidente, ou que praticarem por ordem dêle.

Art. 43. O Senado Nacional se compõe de vinte membros vitalícios. Êste número, mediante proposta do próprio Senado, poderá ser elevado por lei. Em caso de vaga, o novo Senador será eleito pelos Ministros do Supremo Tribunal, dentre cinco nomes indicados pelo próprio Senado. São condições para a investidura no cargo de Senador: 1 . ser brasileiro nato; 2 . ser maior de trinta e cinco anos; 3 . ter reputação ilibada; 4 . haver demonstrado, por atos e obras, notável saber e acentuado espírito público.

Art. 44. Ao Senado compete: 1. elaborar as leis, nos termos do artigo 52 e $53 ; 2$. deliberar sôbre o veto, nos termos do artigo $54 ; 3$. suspender a execução, no todo ou em parte, de lei ou decreto declarado inconstitucional por decisão definitiva do Supremo Tribunal; 4. votar o orçamento; 5. julgar as contas do Presidente da República; 6. tomar, por iniciativa própria, as contas do Presidente da República, mediante designação de comissão especial, quando não forem apresentadas ao Senado dentro dos três primeiros meses do ano; 7. autorizar os empréstimos externos das Províncias e dos Municípios; 8. resolver definitivamente sôbre os tratados e convenções celebrados com os Estados estrangeiros pelo Presidente da República. O Senado não tem a iniciativa da lei, ressalvado o disposto no artigo 58. As deliberações serão tomadas por maioria absoluta de votos. Pode o Senado convocar Ministros de Estado, para que prestem, pessoalmente, informação acêrca de assunto prèviamente determinado. Compete ao

Composição do Senado Nacional.

Competência do Senado. 
próprio Senado elaborar seu regimento interno, dispondo, dentro dos limites das verbas orçamentárias, sôbre a criação e provimento de cargos, polícia interna e tudo mais quanto diga respeito à organização e ao funcionamento de seus serviços.

Garantias dos Senadores.

O que é vedado aos Senadores.
Art. 45. Os Senadores são invioláveis no exercício de suas funções, por suas opiniões, palavras e votos. Não poderão ser presos, salvo em flagrante de crime inafianéável, nem processados criminalmente sem prévia licença do Senado. No caso de flagrante de crime inafiançável, os autos serão remetidos, dentro de quarenta e oito horas, ao Senado, para que êste, pelo voto da maioria de seus membros, aprove, ou não, a prisão do acusado, e autorize, ou não, a competente formação da culpa. Os Senadores não poderãe ser incorporados às fôrças armadas, senão em tempo de guerra e mediante licença do Senado, ficando então sujeitos à legislação militar. Os vencimentos de Senador são iguais aos de Ministro do Supremo Tribunal.

Art. 46. É vedado aos Senadores: 1 exercer qualquer atividade político-partidária; 2 . ser eleitor; 3 . filiarse a Corporação; 4 . ter, exceto cargo no magistério superior ou secundário, qualquer outra função pública, e bem assim qualquer cargo, emprêgo, pôsto, função ou comissão em pessoa jurídica de direito público, entidade autárquica, sociedade de economia mista ou emprêsa concessionária de serviço público, não podendo aceitar, dessas entidades, missão de qualquer natureza; 5 . ter contrato com pessoa jurídica de direito público, entidade autárquica ou sociedade de economia mista, salvo quando o contrato, de caráter geral, obedecer a normas constantes e uniformes, adotadas indistintamente para quaisquer interessados; 6. ser proprietário, diretor ou sócio de emprêsa que goze de favor decorrente de contrato com pessoa jurídica de direito público, ou nela exercer função remunerada; 7 patrocinar causas contra pessioa jurídica de direito público, entidade autárquica ou sociedade de economia mista. A infração 
das alíneas dêste artigo, ou a falta, sem licença, por mais de um mês, importa perda do lugar de Senador, declarada pelo Presidente do Senado. Perderá, igualmente, seu lugar, o Senador cujo procedimento seja reputado, pelo voto de dois terços de seus pares, incompatível com o decôro da Casa.

Art. 47. O Conselho Nacional se compõe de representantes da Nação, eleitos pelo voto secreto dos Conselheiros Municipais e Provinciais. O Vice-Presidente da República é o Presidente do Conselho Nacional. Cada Província e Território terá, no Conselho Nacional, um número de Conselheiros Nacionais que a lei fixará periòdicamente, atendendo ao critério da representação proporcional, mas que não poderá ser maior do que vinte e cinco. A eleição se faz conjuntamente com a do Presidente da República. São condições para a investidura no cargo de Conselheiro: 1. ser brasileiro nato; 2 . ser eleitor; 3 . ser maior de trinta anos.

Art. 48. Compete ao Conselho Nacional: 1. sugerir ao Presidente da República medidas e projetos de lei, que sejam considerados de interêsse geral; 2 . aprovar, mediante voto secreto, a escolha de magistrados nos casos 'determinados em lei, do Procurador Geral da República, dos Ministros do Tribunal de Contas e dos chefes de missão diplomática de caráter permanente; 3 . autorizar o Presidente da República a declarar a guerra e a fazer a paz; 4. dar-lhe o direito de permitir que fôrças estrangeiras transitem pelo território do País, ou, por motivo de guerra, nele permaneçam temporàriamente; 5 . aprovar o estado de sítio proposto ou decretado pelo Presidente da República, assim como a prorrogação dessa medida (Art. 20); 6. autorizar a intervenção do Govêrno Nacional nas Províncias; 7. conceder anistia; 8. aprovar as propostas dos Governos Provinciais sôbre incorporação, subdivisão ou desmembramento de Províncias; 9. autorizar o Presidente e o
Composição do Conselho Nacional.

Competência do Conselho Nacional. 
Vice-Presidente da República a se ausentarem do País; 10. exercer vigilância sôbre os atos do Poder Público, denunciando as irregularidades por ventura verificadas; 11. advertir as autoridades dos perigos que possam ameacar o bem comum; 12. declarar, pelo voto da maioria absoluta de seus membros, a procedência ou improcedência de acusação contra o Presidente da República ou contra os Ministros de Estado para o fim de, no caso de ser admitido o recebimento, submeter-se o acusado a julgamento perante o Supremo Tribunal, nos crimes comuns, ou perante o próprio Conselho Nacional, nos de responsabilidade; 13. julgar o Presidente da República e os Ministros de Estado, nos crimes de responsabilidade. Nas sessões de julgamento, funcionará, como Presidente do Conselho Nacional, o Presidente do Supremo Tribunal. O Conselho Nacional só proferirá sentença condenatória pelo voto de dois terços de seus membros. A pena aplicável pelo Conselho é a perda do cargo, com inabilitação, até cinco anos, para o exercício de qualquer função pública, sem prejuízo da ação competente na justiça ordinária. De qualquer decisão condenatória do Conselho, cabe recurso para o Supremo Tribunal. O próprio Conselho elaborará seu regimento interno, dispondo, dentro dos limites das verbas orçamentárias, sôbre criação e provimento de cargos, polícia interna e tudo o mais que diga respeito à organização e ao funcionamento de seus serviços.

Garantias dos Conselheiros.
Art. 49. Os Conselheiros têm as garantias de que gozam os Senadores. O Conselheiro investido no cargo de Ministro de Estado, Interventor ou Secretário de Província não perde o mandato. Para seu lugar no Conselho, será convocado o respectivo suplente. Não havendo suplente, o Superior Tribunal Eleitoral providenciará para a eleição de um novo Conselheiro, salvo si faltar menos de um ano para o têrmo do período. O Conselheiro eleito terá mandato pelo tempo restante. No fim de cada mandato, o Conselho fixará o subsídio a vigorar durante o período 
seguinte. Havendo omissão desta providência, entenderse-á que a base do subsídio não foi alterada.

Art. 50. Ao Govêrno Nacional compete; 1. fixar a proporção para o cálculo do número de Conselheiros nos Conselhos Provinciais e Municipais; 2. criar e extinguir cargos públicos nacionais, fixando-lhes os vencimentos; 3 . organizar as fôrças armadas, garantir a inviolabilidade das fronteiras e assegurar a defesa do País; 4. autorizar a produção de material bélico, e fiscalizar o comércio do mesmo; 5. superintender, em todo o território nacional, os serviços de polícia marítima, aérea e de fronteiras; 6 . resolver sôbre os limites do território nacional; 7. cunhar e emitir moeda, e instituir bancos de emissão; 8. dispôr sôbre a dívida pública federal e os meios de solvê-la; 9. fiscalizar as operações de estabelecimentos de crédito, de capitalização e de seguro; 10. estabelecer o plano nacional de viação; 11. manter o serviço postal e o correio aéreo nacional; 12 . explorar, diretamente ou mediante autorização ou concessão, os serviços de telégrafos, de rádio-comunicação, de rádio difusão, de telefones interprovinciais e internacionais, de navegação aérea e de vias férreas, que liguem portos marítimos a fronteiras nacionais ou transponham os limites de uma Província; 13. legislar sôbre as seguintes matérias: a) direito civil, comercial, penal, processual, direito do trabalho e direito aeronáutico; b) organização corporativa; e) tributos nacionais; d) diretrizes nacionais de regime penitenciário, de direito financeiro, de seguro e previdência social, de defesa e proteção da saúde; e) produção e consumo; f) diretrizes e bases da educação nacional; g) registros públicos e juntas comerciais; h) organização, instrução, justiça e garantias das polícias militares e condições gerais de sua utilização pelo Govêrno Nacional, nos casos de mobilização ou de guerra; i) desapropriação (Art. 10); j) requisições civis e militares em tempo de guerra; k) regime dos portos e da navegação de cabotagem; l) tráfego interprovincial; m) comércio exte- 
rior e interprovincial, instituições de crédito, câmbio e transferência de valores para fora do País; $n$ ) riquezas do subsolo, mineração, metalurgia, águas, energia elétrica, florestas, caça e pesca; o) sistema monetário e de medidas; título e garantia dos metais; p) naturalização; entrada, extradição e expulsão de estrangeiros; q) emigração e imigração; r) condições de capacidade para o exercício das profissões técnico-científicas e liberais; s) uso dos símbolos nacionais; t) incorporação dos selvícolas na comunhão nacional. A competência do Govêrno Nacional para legislar sôbre as matérias dos itens $d, e, h, j, l, n, q$, e $t$ não exclui legislação provincial supletiva ou complementar. Mediante acôrdo com os Governos Provinciais, poderá o Govêrno Nacional cometer a funcionários provinciais a execução de leis e serviços nacionais ou de atos e decisões de suas autoridades.

Art. 51. O Presidente da República e o Senado são, nacional. por excelência, os órgãos responsáveis pela segurança nacional. Cabe-lhes, na esfera das respectivas atribuições. defender a ordem jurídica do País, contra tudo quanto fira os princípios éticos tradicionais da civilização brasileira. Compete-lhes assegurar à Nação condições de existência digna e tranquila. Para desempenho dessa obrigação, deverão salvaguardar, em tôdas as circunstâncias, os interêsses básicos do Brasil. Dentro de um plano de ação permanente, cumpre-lhes estimular e promover o desenvolvimento econômico do País, assim como combater e extirpar o que possa debilitar as suas fôrças produtivas. É dever supremo do Presidente da República e do Senado repelir, com desassombro, tudo quanto represente ameaça, próxima ou remota, aos direitos indivisiveis de soberania e independência do Estado Brasileiro. 
CAPÍTULO IV

\section{Das leis}

Art. 52. A iniciativa das leis pertence: no plano nacional, ao Presidente da República e às Confederações Corporativas; e, no plano provincial, aos Governadores e às Federações Corporativas (Art. 28). A cada Confederação e Federação Corporativa, pertence a iniciativa das leis sôbre sua respectiva categoria de atividade, não excluída a competência paralela do Presidente da República e dos Governadores.

Art. 53. O projeto de lei, gerado numa Confederação ou produzido pelo Presidente da República, será remetido Elaboração ao Senado Nacional, que dêle enviará cópia, no prazo de três dias, ao Conselho Nacional e à imprensa. No Senado, o projeto é submetido a exame técnico, e considerado quanto a sua conveniência e oportunidade. Pode o Senado requisitar das autoridades públicas e pedir a entidades particulares tôdas as informações de que tenha necessidade, para o esclarecimento do assunto em estudo, inclusive o depoimento pessoal de Ministros de Estado. Tôda a tramitação do projeto pelo Senado pode ser acompanhada por Procurador da República, no caso de projeto presidencial, ou, no outro caso, por procurador especialmente nomeado pela Confederação de que se originou o projeto. A lei proverá êstes procuradores de amplos meios e recursos, para a defesa dos projetos de cujo patrocínio forem incumbidos. Poderá o Senado propôr, à fonte do projeto, emenda a seu mérito, mas não poderá emendá-lo sem aquiescência dessa fonte. Terminados os estudos sôbre o mérito do projeto, será êle submetido ao Plenário. Um relator exporá, minuciosamente, a intenção do projeto, os estudos técnicos a que foi submetido e as conclusões a que chegaram êsses estudos. Depois, para defender o projeto, poderá usar da palavra o procurador da entidade que o gerou. Submetido à discussão e posto a votos,

Iniciativa das leis. 
o projeto estará aprovado se obtiver, a seu favor, maioria absoluta de sufrágios. Se fôr rejeitado, só se poderá renovar dois anos após a rejeição. Uma vez aprovado, o projeto receberá redação definitiva. Em seguida, será enviado à sanção.

Veto.

Art. 54. Se o Presidente da República julgar o projeto, no todo ou em parte, inconstitucional ou contrário aos interêsses nacionais, veta-lo-á, total ou parcialmente, dentro de dez dias úteis, a contar daquele em que o recebeu, e comunicará, no mesmo prazo, ao Presidente do Senado, os motivos do veto. Decorrido o decêndio, o silêncio do Presidente da República importa sanção. Se a sanção fôr negada durante as férias do Senado, o Presidente da República publicará o veto. Comunicado o veto ao Presidente do Senado, êste o submeterá, com as razões que o motivaram, ao conhecimento do Plenário. Terão a palavra o relator do projeto vetado e o procurador da entidade que o apresentou. Posto a votos, considerar-se-á aprovado o projeto que obtiver os sufrágios de dois terços dos Senadores presentes. Neste caso, será o projeto enviado ao Presidente da República para promulgação. Se qualquer lei, depois de sancionada, não fôr promulgada dentro de três dias pelo Presidente da República, o Presidente do Senado a promulgará; e se êste não o fizer em igual prazo, fa-lo-á o Vice-Presidente do Senado. Uma vez promulgada. a lei será imediatamente publicada.

\section{CAPÍTULO $\mathrm{v}$}

\section{Disposições finais}

Dissolução do antigo regime.

Criação do Senado Nacional.
Art. 55. São dissolvidos, nesta data, o Senado Federal, a Câmara dos Deputados, as Assembléias Legislativas dos Estados e as Câmaras Municipais.

Art. 56. Os primeiros candidatos ao Senado Nacional serão escolhidos mediante concurso de titulos. As 
inscrições serão recebidas nas secretarias dos Tribunais de Justiça. Em cada Província, os Desembargadores farão um julgamento preliminar. Desclassificarão os concorrentes que se apresentarem com títulos considerados insuficientes, e organizarão lista dos candidatos vencedores com o máximo de vinte nomes. Na Capital da República, as inscrições serão recebidas na Secretaria do Tribunal de Recursos, cujos juízes farão o julgamento preliminar dos concorrentes, e organizarão, também, lista dos candidatos vencedores, com o máximo de vinte nomes. Tôdas as listas, com os documentos produzidos pelos concorrentes, serão remetidas ao Supremo Tribunal. Os Ministros do Supremo Tribunal julgarão os títulos dos candidatos vencedores em cada Província e na Capital da República, organizando, em seguida, lista dos sessenta candidatos que lhes pareçam apresentar, em todo o País, os títulos mais completos para a investidura senatorial. De entre êstes, o Presidente da República nomeará os vinte Senadores Nacionais.

Art. 57 Em cada Província, o Presidente da República poderá manter, provisòriamente, em seu pôsto, $\mathrm{o}$ Governador em exercício; ou destituí-lo, se assim o exigir o interêsse público. Em caso de destituição do Governador, nomeará em seu lugar, um Interventor. Dentro do prazo de trinta dias, a partir da data desta Constituição, fixará, em decreto, a proporção, a vigorar em todo o País, para o cálculo do número de Conselheiros em cada Conselho Provincial e Municipal. Dentro de igual prazo, a partir da data dêsse decreto, os Governadores e Interventores fixarão o número de Senadores e, para cada Município, o número de Conselheiros. A primeira escolha dos candidatos aos Senados Provinciais será feita pelo sistema adotado para o Senado Nacional (Art. 56). Após julgamento, os Desembargadores desclassificarão os concorrentes que se apresentarem com títulos considerados insuficientes, e organizarão lista dos candidatos vencedores. 
Esta lista conterá nomes em número até três vêzes superior ao número fixado para o Senado. Dentre êsses candidatos, o Presidente da República nomeará os Senadores Provinciais. O Senado, uma vez composto, organizará imediatamente seu regimento interno e, em seguida, elaborará o projeto da Constituição Provincial. Concomitantemente com o concurso dos candidatos a Senador, os Governadores ou Interventores promoverão a primeira eleição para os Conselhos Municipais.

Organismo Judiciário; Fôrças Armadas; funcionalismo público; orçamento da República; Tribunal de Contas; discriminaç̃o de rendas

Incorporacão, divisão e desmembramento de Províncias e Territórios.

Bens da Nação e das Províncias.
Art. 58. Dentro do prazo de um ano, a partir de sua instalação, o Senado Nacional apresentará ao Presidente da República, para sanção, projetos de Leis Constitucionais, dispondo sôbre: 1. o Organismo Judiciário; 2. as Fôrças Armadas; 3. o funcionalismo público; 4. o orçamento da República e o Tribunal de Contas; 5. a discriminação de rendas. Até o início da vigência das referidas leis, regularão as matérias enumeradas neste artigo, as disposições da Constituição de 1946, a elas referentes.

Art. 59. As Províncias podem incorporar-se umas nas outras, dividir-se, ou desmembrar-se para se anexarem a outras, ou formarem novas Províncias, mediante voto dos respectivos Conselhos Provinciais e aprovação do Conselho Nacional. Os Territórios, mediante lei nacional, podem constituir-se em Província, dividir-se ou incorporarse em Província já existente.

Art. 60. Incluem-se entre os bens da nação: 1. os lagos naturais de grande extensão e os cursos dágua de volume considerável, em terrenos de seu domínio ou que banhem mais de uma Província, sirvam de limite com outros países ou se estendam a território estrangeiro; 2. as ilhas fluviais e lacustres nas zonas limítrof es com outros países: 3 . a porção de terras devolutas indispensável à defesa das fronteiras, às fortificações, construções militares e estradas de ferro. Incluem-se entre os bens das Pro- 
víncias os lagos e rios de grande volume existentes em terrenos de seu domínio.

Art. 61. A navegação de cabotagem para o transporte de mercadorias é privativa dos navios nacionais, salvo caso de necessidade pública.

Art. 62. É vedado ao Poder Público: 1. criar distinções entre brasileiros, ou adotar medidas de preferência em favor de quaisquer Províncias ou Municípios; 2. turbar, sem necessidade de ordem pública, a posse exercida pelos selvícolas sôbre as terras onde se achem permanentemente localizados; 3. recusar fé aos documentos públicos. É vedado aos Governos Provinciais e Municipais contrair empréstimo externo sem prévia autorização do Senado Nacional.

Art. 63. O Poder Público protegerá o patrimônio histórico e artístico da Nação, assim como seus monumentos naturais, suas paisagens e localidades de particular beleza.

Art. 64. Os cemitérios têm caráter secular e serão administrados pela autoridade municipal, sem prejuízo do disposto no art. 5. São entretanto admitidos, em casos especiais, a requerimento dos interessados, sepultamentos em prédios e locais reservados, pertencentes a entidades privadas de bôa tradição e indiscutível respeitabilidade.

Art. 65. Só pelo voto da maioria absoluta de seus membros, poderão os Tribunais declarar a inconstitucionalidade de lei ou de ato do Poder Público.

Art. 66. O Brasil mantém representação diplomática junto à Santa Sé.

Inconstitucionalidade de lei ou ato.

Representacão diplomática junto à Santa Sé. 
Guerra.

Art. 67 O Brasil, em caso nenhum, se empenhará em guerra de conquista, direta ou indiretamente, por si ou em aliança com outro Estado. O Brasil só recorrerá à guerra se não couber ou malograr o recurso ao arbitramento ou aos meios pacíficos de solução de conflito.

Símbolos nacionais.

Emenda ì Constitrição.

Art. 68. São símbolos nacionais a bandeira, o hino, o sêlo e as armas vigorantes na data desta Constituição.

Art. 69. Qualquer emenda à Constituição será considerada proposta quando fôr apresentada: 1. pelo Presidente da República; 2 . por mais da metade das Confederações Corporativas. O projeto de emenda será processado de acôrdo com as normas do artigo 53. A emenda estará aceita se fôr aprovada pela maioria absoluta dos Senadores, em duas discussões, entre as quais medeie o prazo de um ano pelo menos.

Art. 70. A presente Constituição entra em vigor nesta data. 